\title{
Mass media and aspiration achievement of children on primary education
}

\author{
Gunartati Gunartati $^{1}{ }^{*}$, Siti Eshah Mokshein ${ }^{2}$ \\ ${ }^{1}$ Sekolah Tinggi Keguruan dan Ilmu Pendidikan (STKIP) Catur Sakti Bantul. Jalan Doktor Wahidin \\ Sudirohusodo, Trirenggo, 55714 Yogyakarta, Indonesia. \\ ${ }^{2}$ Universiti Pendidikan Sultan Idris. Tanjong Malim, Perak Darul Ridzuan 35900, Malaysia \\ * Corresponding Author. E-mail: tatiknurwangid@gmail.com \\ Received: 5 April 2019; Revised: 12 April 2019; Accepted: 29 April 2019
}

\begin{abstract}
Child labor is the social phenomena that not only exist in Indonesia but also in other developing countries. These children work in several sectors including in the small industrial sector. As a young generation, they also must be able to compete in the work world. Therefore, aspiration achievement is an urgent matter and must be considered by stakeholder. On the other hand, the influence of globalization is increasingly global, especially in the field of communication. Representations from this field include on the mass media. Child labor who lives in the global era is also very familiar with the mass media. The study aimed to reveal the influence of information on radio, television and family environment on aspirations achievement of child labor at the leather industry handicraft center in Wukirsari, Imogiri, Bantul. The population of this study was child workers aged 10-14 years, who worked in the leather industry handicraft centers in Wukirsari, Imogiri, Bantul and were still taking study in school, which had a total of 119 child workers. Questionnaire instruments used to obtain data of all variable. The regression analysis technique used to test the hypothesis. The results of the study showed that there was a significant positive influence on the habit to follow information from the mass media and the family environment on the aspirations of child laborers at the leather industry handicraft center in Wukirsari.
\end{abstract}

Keywords: aspirations achievement, child labor, the primary education period

How to Cite: Gunartati, G., \& Mokshein, S. (2019). Mass media and aspiration achievement of children on primary education. Jurnal Prima Edukasia, 7(1). doi:https://doi.org/10.21831/jpe.v7i1.21745

doi https://doi.org/10.21831/jpe.v7i1.21745

\section{Introduction}

Most of the populations in the developing countries live in less profitable condition in which they do not have enough money to bring their children' study possible higher (Saputra \& Munandar, 2017). In fact, they expect that their children could work to earn an income. In here, they possibly try having children graduating from school to become future workers and help the family's economy. A child labor indicates that children of 10-14 years old work at least one hour per week (Febriana, 2010; Nandi, 2016). The certain number of total child labor is very difficult to collect due to a reason for not registered officially. In a micro view, the number of child labors of each area has not shown the same. Quality human resources, especially future young generations who are able to compete are urgent and known issues. A reason is that the future is a century with full competitors from foreign countries. Then, the government must provide wider opportunities with good environment toward the children's development and prospective human resources of Indonesia in the future. Therefore, the formation of learning society must be unarguable. Assumption of learning society as cited by Kuntoro (1997) indicates that learning would help one to solve the problem of speedy competition, change in work and opportunity, as well as other greater challenges. The learning society must be based on the principle of education for all. This principle contains a commitment to give a chance to all people to have education which encourages them to develop optimally. The manifestation of education for all in Indonesia launch on the policy of the 9-year learning obligation movement. The movement subject to children of 6-15 years old is an effort to extend and distribute learning chance to all individuals. Finally, it will develop a better life. 
In other words, the effect of globalization is wider because each member of society, both individual and group, becomes a world society organization. Globalization occurs as a result of progress in science and technology, especially in communication (Firdaus, 2015). Representation of this field generally included on electronic media. Effect of rapid development technologies and communications makes ones preoccupied in a change bringing them to a different condition which makes people different from themselves and their environments (Ngafifi, 2014; Toffler, 1973).

Mass media is a communication tool (Setiawan, 2012; Wafiyati, 2013). In this global era, increasingly recognized that mass media with increasingly sophisticated technological developments are forming and changing human life patterns. Then, the enormity of mass media information in influencing human life also arise question on the effect of the technological development on the younger generation, especially students. Or, when the student enters the workforce. It is a fact that the crisis in Indonesia has widely spread and impacts on increasing the number of poor people to around half of the total population of Indonesia. The conditions will certainly draw a number of children into difficult situations, including children being forced to work to help meet the needs of their families economy.

The development of a child is much influenced by the environment, especially the family environment. The family environment is closely related to several things such as learning achievement, aspiration, and motivation because the family is an environmental factor that primarily influences the sensitive period to determine the child's personality. In the Pucung, Wukirsari, Imogiri, Bantul area, there is a leather industry craft center that is well known in the Special Region of Yogyakarta even in foreign countries through the export of its leather handicrafts. The interesting thing about it is that most of the craftsmen are students. Means that, not only they are students, but they also work in several "home industries" in there.

The child laborers who are also students are the holders of the nation and state life relay. Therefore, it becomes an urgent matter in preparing their future. Education is an effort in that way. However, it is realized that because of the development of science and technology in the field of information and communication, information from other countries can enter easily within the Indonesian community, including child labor. Meanwhile, the challenges of the young generation today are very different from the challenges of the previous generation. Massive information entered or received from various mass media, and various information from other countries that contain different values can form certain attitudes within the community in facing the challenges.

Therefore, child laborers as part of the young generation should receive guidance, training, and education because they are a valuable investment for the glory and safety of the nation and the country in the future. The future of the nation is in their hands. Coaching, training, and education might not effectively achieve the expected goals without information about various things that affect child labors, such information on mass media related to education.

On the other hand, the impact of a prolonged monetary crisis pushes them to be child laborers with a double role; study for their future and work for their life. In this situation, will their education still work? Then, the clear answer to this dilemma is important to find out.

\section{Methods}

The particular study was a non-descriptive descriptive sample approach, because in its implementation using a sample as a respondent. The research did not cause special treatment for a symptom but only revealed the respondent's self and correlation study.

The respondents were child laborers which worked in the leather industry handicraft center in Wukirsari, Imogiri, Bantul. Characteristics of the respondents were children of 10-14 years, work on certain assigned tasks, and currently taking a study in the school. Therefore, the samples determined purposively based on the determined characteristics.

The instruments in data collection stage were the main questionnaire methods. The questionnaire had function to collect data on information of mass media on child labors, data of family environment, and data on the achievement aspiration of child labors. Interview methods also employed as additional methods. And, the results used as information by analyzing the results to test the validity and reliability of computer services.

The study variables consisted of the habit to follow information from television and the habit to follow information from the radio (mass media information) and the family environment 
as variables of effect and achievement aspirations as the affected variables. While the study data that would be collected were qualitativequantitative data.

The analysis technique used descriptivestatistical analysis and inferential statistics (multiple correlation and regression). Descriptive analysis intended to describe the characteristics of each variable in the form of percentage frequency distribution, histogram, standard deviation, mean and mode. Inferential statistical analysis were Product moment correlation, partial correlation and regression analysis which used to test hypotheses. Product moment correlation used to determine the the relationship between variables; partial correlation used to determine the natural relationship between the independent and the dependent variables; and regression analysis used to determine the contribution between the independent and dependent variables. The obtained data type was adjusted to the problems and objectives of the study. Then, data analysis in this study was carried out with the following stages: (1) described the data; (2) tested requirements for analysis; and (3) tested the hypothesis.

\section{Results and Discussion}

The results of the study presented in graphs, tables, or descriptive forms. Analysis and interpretation of these results were needed before discussion. The tables are written in the middle or at the end of each text describing study results/outputs. If the width of the table is not sufficiently to write in half a page, it can be read. Here are the results of this study.

\section{Description of Study Data}

The particular study consisted of four variables; habit to follow the information on the radio (X1), habit to follow the information on television (X2), and the family environment (X3) as independent variables and achievement aspirations as dependent variables. The information on the radio and television classified as information from the mass media. The following description explains the data from each variable. The description of the descriptive data was in the form of mean, median, mode, standard deviation, frequency distribution table and histogram figure of each variable.

Habit to Follow the Information on Radio

Table 1. Distribution of Habit Score Frequency to Follow the Information on Radio

\begin{tabular}{cccc}
\hline No. & $\begin{array}{c}\text { Interval } \\
\text { Class }\end{array}$ & $\begin{array}{c}\text { Absolute } \\
\text { Frequency }\end{array}$ & $\begin{array}{c}\text { Relative } \\
\text { Frequency }(\%)\end{array}$ \\
\hline 1. & $19-21$ & 3 & 3.57 \\
2. & $22-24$ & 5 & 5.95 \\
3. & $25-27$ & 27 & 32.14 \\
4. & $28-30$ & 40 & 47.62 \\
5. & $31-33$ & 8 & 9.52 \\
6. & $34-36$ & 1 & 1.19 \\
\hline & Total & 84 & 100.00 \\
\hline
\end{tabular}

Based on the categorization, category of habit to follow the information on radio is presented in Table 3. Based on the Table 3, it proved that the mean observation of 27.738 was in a sufficiently good category. Thus, it concluded that the habit to follow the information on the radio among child laborers in the leather industry center in Wukirsari, Imogiri, Bantul, was in a sufficiently good category.

Habit to Follow the Information on Television

Table 2. Distribution of Habit Score Frequency to Follow the Information on Television

\begin{tabular}{cccc}
\hline No. & Interval Class & $\begin{array}{c}\text { Absolute } \\
\text { Frequency }\end{array}$ & $\begin{array}{c}\text { Relative } \\
\text { Frequency }\end{array}$ \\
\hline 1. & $25-27$ & 5 & 5.95 \\
2. & $28-30$ & 32 & 38.10 \\
3. & $31-33$ & 34 & 40.48 \\
4. & $34-36$ & 11 & 13.10 \\
5. & $37-39$ & 2 & 2.38 \\
6. & $40-42$ & 0 & 0.00 \\
\hline & Total & 84 & 100.00 \\
\hline
\end{tabular}

Based on Table 2, the highest score is in the class interval from 31 to 33 with an absolute frequency of 34 and the relative frequency is $40.48 \%$. In fact, it proved that the mean observation of 31.119 categorized in good. Thus, it concluded that the habit to follow the information on television among child laborers in the leather industry handicraft center in Wukirsari, Imogiri, Bantul, is in an excellent category.

Table 2. Distribution of Habit Frequency to Follow the Information on Radio Based on Category

\begin{tabular}{ccccc}
\hline Limit of Category & Interval & Amount & Percentage & Information \\
\hline$>(\mathrm{X}+1 \mathrm{SD})$ & $30-40$ & 20 & 23.81 & High \\
$(\mathrm{X}-1 \mathrm{SD})-(\mathrm{X}+1 \mathrm{SD})$ & $19-29$ & 64 & 76.19 & Moderate \\
$<(\mathrm{X}-1 \mathrm{SD})$ & $8-18$ & 0 & 0.00 & Low \\
\hline
\end{tabular}


Jurnal Prima Edukasia, 7 (1), 2019 - 76

Gunartati Gunartati, Siti Eshah Mokshein

Table 4. Distribution of Habit Frequency to Follow the Information on Television Based on Category

\begin{tabular}{ccccc}
\hline Limit of Category & Interval & Amount & Percentage & Information \\
\hline$>(\mathrm{X}+1 \mathrm{SD})$ & $34-45$ & 13 & 15.48 & High \\
$(\mathrm{X}-1 \mathrm{SD})-(\mathrm{X}+1 \mathrm{SD})$ & $21-33$ & 71 & 84.52 & Medium \\
$<(\mathrm{X}-1 \mathrm{SD})$ & $9-20$ & 0 & 0.00 & Low \\
\hline
\end{tabular}

Table 5. Distribution of Score Frequency of Family Environment

\begin{tabular}{cccc}
\hline No. & Interval Class & Absolute Frequency & Relative Frequency \\
\hline 1. & $98-103$ & 5 & 5.95 \\
2. & $104-109$ & 18 & 21.43 \\
3. & $110-115$ & 22 & 26.19 \\
4. & $116-121$ & 25 & 29.76 \\
5. & $122-127$ & 12 & 14.29 \\
6. & $128-133$ & 2 & 2.38 \\
\hline & Total & 84 & 100.00 \\
\hline
\end{tabular}

Table 6. Distribution of Frequency of Family Environment Based on Category

\begin{tabular}{ccccc}
\hline Limit of Category & Interval & Amount & Percentage & Information \\
\hline$>(X+1 S D)$ & $114-155$ & 49 & 58.33 & High \\
$(\mathrm{X}-1 \mathrm{SD})-(\mathrm{X}+1 \mathrm{SD})$ & $73-113$ & 35 & 41.67 & Medium \\
$<(\mathrm{X}-1 \mathrm{SD})$ & $31-72$ & 0 & 0.00 & Low \\
\hline
\end{tabular}

Table 7. Distribution of Score Frequency of Achievement Aspiration

\begin{tabular}{cccc}
\hline No. & Interval Class & Absolute Frequency & Relative Frequency \\
\hline 1. & $89-93$ & 5 & 5.95 \\
2. & $94-98$ & 8 & 9.52 \\
3. & $99-103$ & 24 & 28.57 \\
4. & $104-108$ & 27 & 32.14 \\
5. & $109-113$ & 19 & 22.62 \\
6. & $114-118$ & 1 & 1.19 \\
\hline & Total & 84 & 100.00 \\
\hline
\end{tabular}

Table 8. Distribution of Frequency of Achievement Aspiration Based on Category

\begin{tabular}{ccccc}
\hline Limit of Category & Interval & Amount & Percentage & Information \\
\hline$>(\mathrm{X}+1 \mathrm{SD})$ & $89-120$ & 84 & 100.00 & High \\
$(\mathrm{X}-1 \mathrm{SD})-(\mathrm{X}+1 \mathrm{SD})$ & $56-88$ & 0 & 0.00 & Medium \\
$<(\mathrm{X}-1 \mathrm{SD})$ & $24-55$ & 0 & 0.00 & Low \\
\hline
\end{tabular}

Table 9. Correlation Coefficient of Correlation, Beta, Std. Beta, Multiple Correlation and Determinant Coefficient

\begin{tabular}{cccccc}
\hline Predictor & $\begin{array}{c}\text { Correlation Coefficient } \\
\mathrm{r}_{\mathrm{xy}}\end{array}$ & $\begin{array}{c}\text { Beta } \\
(\mathrm{b})\end{array}$ & $\begin{array}{c}\text { Beta Standard } \\
(\mathrm{B})\end{array}$ & $\begin{array}{c}\text { Multiple Correlation } \\
\mathrm{R}_{\mathrm{y}(123)}\end{array}$ & $\begin{array}{c}\text { Determinant } \\
\text { Coefficient } \mathrm{R}^{2} \mathrm{y}(123)\end{array}$ \\
\hline $\mathrm{X}_{1}$ & 0.415 & 0.393 & 0.181 & 0.626 & 0.39153 \\
$\mathrm{X}_{2}$ & 0.427 & 0.562 & 0.243 & & \\
$\mathrm{X}_{3}$ & 0.545 & 0.316 & 0.391 & & \\
Constant & & 39.529 & & & \\
\hline
\end{tabular}

Table 10. Summary of Regression Analysis

\begin{tabular}{cccccc}
\hline Source of Variation & $\mathrm{db}$ & $\mathrm{JK}$ & $\mathrm{RK}$ & $\mathrm{F}_{\text {reg }}$ & $\mathrm{P}$ \\
\hline Residual regression & 3 & 1059.7881647 .021 & 353.263 & 17.1 & 0.000 \\
& 80 & & 20.588 & 59 & \\
\hline Total & 83 & 2706.810 & & & \\
\hline
\end{tabular}

\section{Workplace}

Based on Table 5, the highest score was in the class interval from 116 to 121 with an abso- lute frequency of 25 and the relative frequency of 29.76. In fact, it proved that the mean observation of 114.524 was in the high category. Thus it concluded that the family environment of child 
labors in the leather industry center in Wukirsari, Imogiri, Bantul, is in a good category.

Achievement Aspiration

In fact, it proved that the mean observation of 104.119 was in the high category. Thus, it concluded that the achievement aspiration of child labors in the leather industry center in Wukirsari, Imogiri, Bantul, is in a high category.

Testing of Hypotheses

\section{Testing of First Hypothesis}

The results of the partial correlation analysis of the first level between information on radio and achievement aspirations, where information variables on television and family environment controlled $\left(\mathrm{r}_{1 \mathrm{y}-23}\right)$ produced a correlation coefficient of $=0.161$; and $\mathrm{t}$ count of 1.851 with $p=0.068$. In fact, it proved that $p>0.05$, it concluded that Ho accepted (supported) and $\mathrm{Ha}$ rejected. And, it concluded that there was no significant effect on the habit to follow the information on the radio and the achievement aspiration of child labors in the leather industry handicraft center in Wukirsari, Imogiri, Bantul.

\section{Testing of Second Hypothesis}

The results of the partial correlation analysis of the second level between information on television and achievement aspiration, where information variables on radio and family environment controlled $\left(\mathrm{r}_{2 \mathrm{y}-13}\right)$ produced a correlation coefficient of $=0.224 ; \mathrm{t}$ count $=2.574$ with $\mathrm{p}=$ 0.012 . Because $\mathrm{p}<0.05$; then Ho rejected and $\mathrm{Ha}$ accepted.

Thus, it concluded that there is a significant effect on the habit to follow the information on television on the achievement aspiration of child labors in the leather industry handicraft center in Wukirsari, Imogiri, Bantul. The higher the information from television, the higher the aspirations will be obtained. On the other hand, the lower the information on televisionn, the lower the aspirations of achievement will be obtained.

\section{Testing of Third Hypothesis}

From the results of the partial correlation analysis of the second level between the family environment with achievement aspirations, where information variables from the radio and information from television are controlled ( $\mathrm{r} 3 \mathrm{y}-$ 12) produced a correlation coefficient of $=0.346$; $\mathrm{t}$ count $=3.965$ with $\mathrm{p}=0.000$. Because $\mathrm{p}<0.05$; then Ho is rejected and $\mathrm{Ha}$ is accepted.
Thus, it can be concluded that there is a significant effect on the family environment on the achievement aspiration of child labors in the leather industry handicraft center in Wukirsari, Imogiri, Bantul. The better the family environment, the higher the achievement aspiration; on the other hand, the better the family environment, the lower achievement aspiration.

\section{Testing of Fourth Hypothesis}

Multiple regression analysis used to test the hypothesis with three following predictors: the habit to follow information on the radio $\left(\mathrm{X}_{1}\right)$; habit to follow information on the television $\left(\mathrm{X}_{2}\right)$; and family environment $\left(\mathrm{X}_{3}\right)$; and as a criterion of achievement aspiration (Y). Regression analysis was carried out with SPSS Version 10.05 software (full regression analysis presented in appendix 6); the results of the calculation presented in Table 9.

From Table 9, the multiple correlation coefficient $R_{y(123)}$ is 0.626 . Aiming to find out the value of multiple correlation coefficients is significant or not, $\mathrm{F}$ regression must be found. And, based on the calculation results, the $\mathrm{F}$ regression value is 17.159 . Table 10 presented a summary of regression analysis.

Based on Table 10, the value of $F_{\text {reg }}$ results is 17.159; where $\mathrm{p}<0.05$. Thus, it concluded that there is a significant effect on the habit to follow information on the mass media and family environment on the aspirations of child laborers at the leather industry handicraft center in Wukirsari, Imogiri, Bantul.

And, based on the results of the analysis, the coefficient of determination obtained $\left(\mathrm{R}_{\mathrm{y}(123)}^{2}\right.$ $=0.392$. This means that the aspirations of child labors at the leather industry craft center in Wukirsari, Imogiri, Bantul might obtain information on the mass media (radio and television) and family environment of $39.153 \%$.

\section{Discussion}

\section{Results of Discussion for First Problem}

The results of the descriptive analysis concluded that the habit to follow information from the radio on child laborers in the leather industry craft center in Wukirsari, Imogiri, Bantul was in the medium category; effective contribution was $7.495 \%$, while achievement aspirations was high. Test of the first hypothesis showed that there was no significant effect on the habit to follow information from the radio on the aspirations of child laborers at the leather 
industry handicraft center in Wukirsari, Imogiri, Bantul. This is shown by $r_{1 y-23}$ of 0.161 and $t$ of 1.851 where $\mathrm{p}>0.05$.

The factors behind the results of the first hypothesis testing are: (1) radio is a medium that provide information in fast and wider range compare to other mass media. However, this medium also has weaknesses such as: cannot be seen by listeners, the content of the broadcast is easily forgotten and not everything can be reported (Sunyoto, 1998). Because of these weaknesses, in certain cases, the information cannot be understood properly by listeners. So the role of radio as an instrument to expand knowledge cannot be maximized. It is true evidence for child labors due to the weakness of the radio does not have much effect on their achievement aspirations, especially child laborers often listen to the radio while working. In this case, the information they receive cannot be optimal; (2) the mass media emerged in this global era were so diverse. They tried to present the best and as actual as possible information. Such conditions make a tight competition between the media and the weaknesses of the radio make radio might be less competitive; (3) the results of the study indicated that the most popular and most often heard by child laborers is drama series. The effect of this program on the achievement aspiration of child labors is not too straightforward, even though it is undeniable that the drama series is indeed full of moral messages that are very educational for listeners.

\section{Results of Discussion for Second Problem}

The results of the descriptive analysis concluded that the habit to follow information on television for child laborers in the leather industry craft center in Wukirsari, Imogiri, Bantul was in the medium category.

The results of test the second hypothesis indicated that there is a significant positive effect on the habit to follow information from the televisi on the achievement aspiration of child labors in the leather industry craft center in Wukirsari, imogiri, bantul. This finding indicated by $r_{2 y-13}$ of 0.224 and $t$ of 2.574 where $p<0.05$, so that the correlation was significant. The better the habit to follow information from television, the higher the achievement aspirations of child labors will be obtained; on the other hand, the less good the habit to follow information from television, the lower the aspirations of child labors.
The results of this analysis were relevant to (Boyer, 1996; Wedadjati, 2009) that television provided sprinkle curiosity in children and open their view to a world wide. Through its charm, children can travel anywhere. They can see the moon, river or explore imaginary countries. Therefore, by watching selectively, television can give a large contribution to the readiness of children for school and achievement.

Television can indeed give children a wider experience, as well as a deeper understanding on their outer world. By watching television, children will also be assisted to learn to think, to reflect and acquire new knowledge and connect ideas. In other words, television can train children to think critically, where such mindset is needed to improve children' achievement aspirations. Especially, viewed by television's effects as argued by Hidayati (1998): First, television broadcasts can foster a desire to acquiren knowledge because what is seen on the television screen is very limited. So, children are motivated to follow what they see as possible by reading a book or magazine to increase knowledge. Second, add vocabulary. Not only vocabulary addition, but children also feel pride. And, this output can be obtained through television. But, the problem is, to whom the children must ask when they do not understand the new words. This case is telling us the importance of mentoring; played by parents or adults. This is important factor aiming the television might use as a learning medium for children. Third, television has effect on increasing children's creativity. Especially, children who are creative by watching television, they will bring more new ideas. On quiz shows and children's creations, for example, there will be many creations that can be copied and developed. Fourth, television provides a variety of knowledge than the surrounding environment or others, such as knowledge about a broad life, natural beauty, the rapid development of science, and so on. Starting here, the child has broad insight to think openly, extroverted, able to understand the truth from anywhere, and earnestly to move forward. This kind of conditions was also created in child labor in this study, such on the indicator when they saved a portion of their income for their future, and they also wanted to continue their education to a higher level.

In the end, television might have a positive effect on children, the environment and the role of parents who are ready to assist and be ready to speak. In sum, parents or other adults play a decisive role as tutors. 


\section{Results of Discussion for Third Problem}

The results of the descriptive analysis concluded that the family environment of child labors in the leather industry handicraft center in Wukirsari, Imogiri, Bantul was in the good category.

The results of test the third hypothesis provec that there was a significant positive effect on the family environment on the achievement aspiration of child labors at the leather industry handicraft center in Wukirsari, Imogiri, Bantul. This finding was shown by $\mathrm{r}_{3 y-12}$ of 0.346 and $t$ of 3.965 where $\mathrm{p}<0.05$; so, the correlation was significant. The better the family environment, the higher the achievement aspirations of child labor will be obtained; on the other hand, the worse the family environment, the lower the aspirations of child labors.

Relevant finding by (Choiri, 2017; Keeves, 1972) found out that there were at least 3 (three) environments effects the children in the process of learning activities and other activities in their lives, namely: home environment, school environment, and peer groups. Keeves also found a correlation coefficient of 0.57 between family environment and children' learning achievement.

While Johnstone (1979) reported that the process dimensions of the family environment gave biggest contribution to students' achievement than other external school factors. Therefore, the family environment must be created as moderately as possible, especially parents need to think based on the children' mind. The aim was that the child will eventually be more interested in his family than other people or other things that might be out of him.

In this case, the role of parents' main family environment is big. Parents are first and foremost teachers for children. The child first learns and places trust on parents. This opportunity must use as well as possible and as much as possible to instill everything about the basics of goodness, before children are affected by the environment, friends, and others. This is where an effort is needed to create a conducive family environment. Although, this statement does not ensure as well. Many people were born from ordinary families, and many destructive children were born from families, including from a rich family environment. But, this can also occurs on otherwise, such excellent children were born from a rich family environment. This is the importance of knowing children's education well through make a good family environment. This statement also relevant to (Cooley, 1998; Widiastuti, 2017) that the most important aspect of a family environment should create a well condition due to will make children have early social experiences. So, when a child is blended into a situation, they will not experience many obstacles.

\section{Results of Discussion for Fourth Problem}

The results of test the fourth hypothesis proved that there was a significant positive effect on the habit to follow information from the mass media (radio and television) and the family environment towards achievement aspirations in child labors in the leather industry handicraft center in Wukirsari, Imogiri, Bantul.

Based on the calculation results, the value of $\mathrm{R}=0.626$ and $\mathrm{F}=17.159$; where $\mathrm{p}<0.05$. Because $\mathrm{p}<0.05$; the correlation was significant. It means that there was a significant positive effect on the habit to follow mass media and family information together on the aspirations of child laborers in the leather industry handicraft center in Wukirsari, imogiri, Bantul.

Furthermore, it explained that the achievement aspirations of child labors can be explained by the habit to follow information from the mass media and family environment by $39.2 \%$. Means, an increase or decrease in the achievement aspiration of child labors can be explained by the habit to follow information from the mass media and family environment by $39.2 \%$; while the remaining $60.8 \%$ is explained by other variables which is not examined in this study.

Based on the findings, the effective contribution of each predictor to the criterion can also be explained as follows: effective contribution of predictor $\mathrm{X}_{1}$ (habit to follow information from radio) of $7.495 \%$. This finding proved that the habit to follow information from radio $\left(\mathrm{X}_{1}\right)$ plays an important role in increasing the achievement aspirations of child labors. Effective contribution of $\mathrm{X}_{2}$ predictor (habit to follow information from television) was $10.349 \%$. This proved that the habit to follow information from television $\left(\mathrm{X}_{2}\right)$ plays an important role in increasing the achievement aspirations of child laborers. The family environment $\left(\mathrm{X}_{3}\right)$ gave an effective contribution of $21.308 \%$; indicated that the family environment played a very important role in increasing the achievement aspirations of child labors.

\section{Conclusions}

There was no significant effect on the habit to follow information on the radio toward the 
achievement aspiration of child labors in the leather industry handicraft center in Wukirsari, Imogiri, Bantul. First, there was a significant positive effect on the habit to follow the information on television toward the achievement aspiration of child labors in the leather industry handicraft center in Wukirsari, Imogiri, Bantul. The better the habit to follow information from television, the higher the achievement aspirations of child labors will be obtained. Second, There was a significant positive effect on the family environment toward the achievement aspiration of child labors in the leather industry handicraft center in Wukirsari, Imogiri, Bantul. The better the family environment, the higher the aspirations of child labor will be obtained. Third, There was a significant positive effect on the family environment toward the achievement aspirations of child laborers in the leather industry handicraft center in Wukirsari, Imogiri, Bantul. The better the family environment, the higher the aspirations of child labors will be obtained. Fourth, There was a significant positive effect on the habit to follow the information on the mass media and family environment toward aspirations of child laborers in the leather industry handicraft center in Wukirsari, Imogiri, Bantul. The habit to follow the information on the radio made an insignificant-effective contribution of $7.495 \%$; the habit to follow information from television made a significant-effective contribution of 10.349\%; and the family environment made a significant effective contribution of $21.308 \%$. This finding means that information on radio, television and family environment were the factors that affect child labor aspirations beside other factors which were not examined in this study.

\section{References}

Boyer, E. L. (1996). The scholarship of engagement. Bulletin of the American Academy of Arts and Sciences, 49(7), 1833.

Choiri, M. M. (2017). Upaya pemanfaatan lingkungan sekitar sebagai sumber belajar anak. Refleksi Edukatika: Jurnal Ilmiah Kependidikan, 8(1), 89-98. doi: https://doi.org/10.24176/re.v8i1.1793

Febriana, R. (2010). Analisis faktor-faktor yang mempengaruhi jam kerja pekerja anak di Kota Palembang. Kajian Ekonomi, 9(2), 192-214.
Firdaus, F. (2015). Dinamika perubahan sosial masyarakat di sekitar Permandian Wae Pellae Desa Kampala Kecamatan Sinjai Timur Kabupaten Sinjai. Dissertation. Pascasarjana Universitas Negeri Makassar.

Hidayati, A. (1998). Televisi dan perkembangan sosial anak. Yogyakarta: Pustaka Pelajar.

Johnston, D. H. (1979). Journalism and the media: An introduction to mass communications. Barnes \& Noble Books.

Keeves, J. P. (1972). Educational environment and student achievement: A Multivariate study of the contributions of the home, the school and the peer group to change in mathematics and science performance during the first year at secondary school. Dissertation, Almqvist \& Wiksell.

Kuntoro, S. (1997). Pengembangan masyarakat belajar dalam kerangkapembangunan. Jurnal Cakrawala Pendidikan, 1(1). doi:https://doi.org/10.21831/cp.v1i1.9223

Mulyono, Y. B. (1988). Pendekatan analisis kenakalan remaja dan penanggulangannya. Yogyakarta: Kanisius.

Nandi, N. (2016). Pekerja anak dan permasalahannya. Jurnal Geografi Gea, $6(1)$.

Ngafifi, M. (2014). Kemajuan teknologi dan pola hidup manusia dalam perspektif sosial budaya. Jurnal Pembangunan Pendidikan: Fondasi dan Aplikasi, 2(1).

Saputra, W., \& Munandar, B. (2017). Keputusan mempunyai anak bagi penduduk migran di pemukiman kumuh Kota Palembang. Seminar Nasional Kependudukan \& Kebijakan Publik, 1(1).

Setiawan, A. R. (2012). Citra UMS dalam harian Solopos dan Joglosemar (Analisis Framing Pemberitaan Harian Solopos dan Joglosemar dalam kasus dugaan terorisme di UMS). Doctoral dissertation, Universitas Muhammadiyah Surakarta.

Sunyoto, W. D. H. (1998). Seluk beluk programa radio. Yayasan Kanisius

Toffler, A. (1973). The culture consumers: A study of art and affluence in America. Vintage Books. 
Jurnal Prima Edukasia, 7 (1), 2019 - 81

Gunartati Gunartati, Siti Eshah Mokshein

Wafiyati, L. (2013). Ekologi media di iklan display aplikasi teori Niche melalui iklan display pada surat kabar harian Solopos dan Joglosemar periode 17 Desember 2012-15 Januari 2013. Doctoral dissertation, Universitas Muhammadiyah Surakarta.

Wedadjati, R. S. (2009). Hubungan antara penilaian anak terhadap cerita film anak di televisi dengan kemampuan empati pada anak usia sekolah dasar. Jurnal
Fakultas Hukum UII, 32(72), 185-196.

doi:

https://doi.org/10.20885/unisia.vol32.iss7 2.art6

Widiastuti, R. Y. (2017). Dampak perceraian pada perkembangan sosial dan emosional anak usia 5-6 tahun. Jurnal PG-PAUD Trunojoyo: Jurnal Pendidikan dan Pembelajaran Anak Usia Dini, 2(2), 7686.. 